\title{
Transdisciplinarity: letting arts and science teach together
}

\author{
Pam Burnard ${ }^{1}$ (D) - Laura Colucci-Gray ${ }^{2}$ (D) $\cdot$ Pallawi Sinha $^{3}$ (I)
}

Published online: 19 April 2021

(C) Australian Curriculum Studies Association 2021

Keywords Posthumanism $\cdot$ STE(A)M $\cdot$ Transdisciplinary pedagogy $\cdot$ Diffractive analysis

\section{Part 1: the case}

The arts excite, amaze, inspire and move us. They illuminate and enrich our lives and deepen our understanding of who we are and how we make sense of the world. 'STEAM education', with its addition of 'arts' to STEM subjects, is a new construct, developed outside formal curricula, yielding the promise of pedagogical innovation, yet it remains a complex and highly contested concept. On the one hand, STEAM builds upon the economic drivers which characterise STEM; an alignment of the disciplinary areas that allegedly have the greatest impact on a developed country's gross domestic product. On the other hand, the addition of the arts - as handmaiden to STEM - is often seen to further diminish and marginalise arts in the curriculum. While their inclusion may point to the recovery of educational aims and purposes which exceed economic growth, for example by embracing social inclusion, community participation or sustainability agendas, for many teachers STEAM spells out controversial, undesirable subject hierarchies contributing to the crisis in contemporary arts education. Central to understanding the pedagogic intricacies and educational opportunities offered by STEAM is the interrogation of the role and status of the arts in relation to STEM subjects, and the need for curriculum reform.

Pam Burnard

pab61@cam.ac.uk

Laura Colucci-Gray

laura.colucci-gray@ed.ac.uk

Pallawi Sinha

p.sinha@uos.ac.uk

The University of Cambridge, Cambridge, UK

2 The University of Edinburgh, Edinburgh, Scotland

3 University of Suffolk, Ipswich, UK
This article is an attempt to rethink and reposition STEAMbased education where arts and sciences are not separate or even separable endeavours, but rather combine as transdisciplinary configurations. In a world further fractured by the ongoing existential crises of the COVID-19 global pandemic and the precarity of human life on Earth, there is a pressing need to develop alternative ways of knowing and being. This article draws upon the efforts of artists and scientists (see Burnard and Colucci-Gray 2020) to make a case for posthumanist transdisciplinary pedagogies, seeking to bring forth collective and sustainable futures.

The big questions for us all are: how can we reconcile the object-focused thinking leading to 'abstraction' with the contextually focused thinking, which puts things into relation? In addition, how can we move from the detailed knowledge accumulated by the singular disciplines, to the breadth of understanding that is derived from viewing the world from the long-term perspective of ecological and evolutionary thinking (Colucci-Gray 2020). These are the questions which underpin our analysis of the debates associated with STEAM education. On the one hand, the acronym points to the separateness of singular disciplines, each one characterised by specific methods, units of measurement and concerns. On the other hand, viewing the singular disciplines as part of multiple configurations, points to a process of understanding, which engages a plurality of mental faculties. For example, from acquiring and assimilating the facts (i.e. that in biology there is always an intermediary organism) to re-viewing the same information from a different methodological stance (i.e. one which emphasises temporality and movement, see Burnard et al. 2020 or one which looks for multiple interconnections, see Colucci-Gray et al. 2013). Allowing for a multiplicity of ways of knowing is essential to deal with the complexity of a world in transformation, whereby no single perspective is valid all of the time, but rather, a plurality of legitimate perspectives is needed (Funtowicz and Ravetz 1994). 


\section{Why do transdisciplinary dialogues matter?}

Petrie (1992) writes: "The notion of transdisciplinarity exemplifies one of the historically important driving forces in the area of interdisciplinarity, namely, the idea of the desirability of the integration of knowledge into some meaningful whole" (p. 230). While advocating integration, transdisciplinary thinking does not exclude or refuse the existence of disciplinary thinking. Disciplinary thinking is characterised by specific core metaphors and concepts, particular ways of structuring experience in the field, specialised methods for investigation and specific means for assessing knowledge claims. However, transdisciplinarity seeks to de-couple the specific language of a discipline from its original context, in order to open up new possibilities for viewing and experiencing the same phenomenon. This process may begin as a 'dialogue' across disciplines. For example, the word 'cell' is used to refer to two very specific and central concepts in physics and in biology. In physics, a cell or 'battery' is defined as an energy source providing an electrical potential difference between its two terminals. Whereas, in biology, a cell represents the smallest structural and functional unit of an organism with a set of identifiable features, such as organelles and membranes. Talking about 'cells' is hardly a point of dialogue between the two realms of knowledge. That said, by shifting attention from its descriptive features and focusing on the physical exchanges of particles and dynamic processes taking place in the cell an important commonality can be found: the transfer of materials and energy through the 'cell'.

Encouraging the use of a word - such as 'cell' - in ways that are different from those in which it was originally used enables us to appreciate new features of the same event. According to Deleuze and Guattari (1987), relinquishing the power of the 'sign' which crystallises the experience of reality into a given word, is the equivalent of a de-territorialisation, which enables new points of conjunction to be found, as happens in dialogue, when two different ideas are compared and shared.

Transdisciplinarity has been described as a practice that transgresses and transcends disciplinary boundaries ... and seems to have the most potential to respond to new demands and imperatives. This potential springs from the characteristic features of transdisciplinarity, which include problem focus (research originates from and is contextualized in 'real-world' problems), evolving methodology (the research involves iterative, reflective processes that are responsive to the particular questions, settings, and research groupings) and collaboration (including collaboration between transdisciplinary researchers, disciplinary researchers and external actors with interests in the research). (Russell et al. 2008, p. 460-461)
Experiences of transdisciplinary collaboration have also been documented amongst teachers and teacher educators in Australia (MacDonald et al. 2019) where the STEAM agenda appears to be growing. In reporting their own experience of transdisciplinary working, the authors illustrate dispositions and qualities that transcend their disciplines such as empathy, openness to new ideas and experiences, 'bravery' as openness to failure, and trust (Smith and Henriksen 2016). As a collective of people with different backgrounds and professional orientations, they recognise the power of creative metaphoric constructs that resonate with embodied experiences as a compelling means to articulate new perspectives and connections.

Hence, in order for transdisciplinarity to come into being a different professional stance is needed, one which Perry (2020) refers to as 'pluriversality', referring to the 'surplus' of meanings and ways of learning which may be generated to enable the complexity of a changing world to come into the realms of our experience. We take this proposition as a generative point of departure for reformulating the purpose of STEAM education in ways that positively re-affirm the roles and responsibilities of both the sciences and the arts.

\section{Part 2: the evidence}

This section introduces the theoretical framework enabling us to capture the deterritorialisation of disciplines and how transdisciplinarity is performed and galvanised by rhizomatic inquiry and diffraction. The dissatisfactions with the assumptions underpinning the traditional proposition of 'STEM plus Arts' (as discussed earlier) directed us to rhizomatic inquiry, as a form of radical methodological innovation in the STEAM education community. This approach was introduced by Deleuze and Guattari (1987) who proposed that there is no beginning or end to the process or phenomenon of thinking. That is, knowledge making is not static and separable from the living and non-living world; instead it occurs in the form of assemblages made up of groups, ideas, elements or systems that are continually intertwining to 'do something, to produce something' (Fox and Alldred 2013, p. 403).

We employ the biological concept of a rhizome (or tuber such as, say, ginger), which spreads out in an unruly fashion. As it ruptures in its unpredictable directions, it throws us off onto another path, allowing us to break with old habits and form new ones, making the familiar unfamiliar, and offering the space to make the unfamiliar familiar. Accordingly, we conceive of knowledge as rhizomatic, organising laterally without hierarchies, and constantly open to de- and reterritorialisation of notions, norms and processes that narrowly define disciplines, phenomena, and activities. This enables a more fluid exploration of the multiplicities in thinking about and doing arts, sciences, mathematics and other disciplines as 
'ways of being' located within learners' socio-cultural, economic and political conditions.

Reading about rhizomatic inquiry led us to American posthumanist theorist and quantum physicist Karen Barad's diffractive analysis. Diffraction means "to break apart in different directions" (Barad 2014 p. 168). Diffraction patterns can be observed in water waves, as well as sound waves and light waves. Where the waves interfere or overlap they create an interference pattern or 'superposition' (Barad 2007, p. 76). Such entanglements are 'highly specific configurations' that require precise apparatuses to study them as they alter with every intra-action. ${ }^{1}$ As Barad (2007) explains, "it is not so much that they change from one moment to the next or from one place to another, but that space, time, and matter do not exist prior to the intra-actions that reconstitute entanglements" (p. 74).

That is, diffraction understands phenomena as inherently different and differing in terms of time, space and matter, but also as deeply relational. Diffraction may not only be a research methodological tool but also a pedagogical tool for meaning-making in the subject and in the human subject.

The same can be said for its troubling of the outdated hegemony of siloed disciplines with their 'either/or' logic. Posthumanism and diffractive analysis objects to the 'epistemic violence' (Braidotti 2019 p. 39) done by humanism. By re-instating affect and sense experience as a prime locus of learning about ourselves and our surrounding, learning is construed 'horizontally'. As opposed to simple 'acquisition of concepts', learning becomes a prime locus of understanding our dependence on others, humans and non-humans. In this view, the relationship between arts and sciences calls to be reviewed from one of alternate subservience to one of close and integrated correspondence.

Knowledge is not a separate component within a selfcontained 'body'; instead we come to live and think through assemblages in the flesh, emerging from the material and energetic assemblages of the Earth. A diffractive analysis invites

\footnotetext{
${ }^{1}$ For Barad (2007), existence is not inseparable from the world (living and non-living), 'but rather, individuals emerge through and as part of their entangled intra-relating' (p. ix). She avers that time and space, matter and meaning, human-non-human are entangled, iteratively reconfigured through each intra-action, making it impossible to any absolute distinctions between 'beginning and returning, continuity and discontinuity, here and there..' (ibid). Thus intra-activity is that which builds an understanding of the inseparability of the "observed object" and the "agencies of observation", the observer-observed, and how our intra-action with other bodies (both human and nonhuman) offers subjectivities and performative enactments. In our study (see Burnard, Sinha, Steyn et al. 2020), through the agentially intra-acting formations, phenomenon and components of the two disciplines, mathematics and art, we were able to (re)formulate math and art concepts and practices, and re-turn the gaze into a dialogic math-art connection-making and doing, or what Barad refers to as ethico-onto-epistemology. Here, too, as authors of the article, we have "intra-actively" written with each other since "writing is not a unidirectional practice of creation that flows from author to page, but rather the practice of writing is an iterative and mutually constitutive working out, and reworking (Barad 2007, p. x).
}

different sets of questions and (re)configurings that lead to alternative ways of 'seeing', 'knowing' and 'doing' education and research. In these ways, diffraction produces a 'cuttingtogether apart' driven by affect, and by the practice, place and people involved in the phenomenon or activity. Diffraction is thus driven by the affective, discursive, historical, sociocultural and material conditions that exceed the disciplinary 'gaze', to represent the ongoing folding-unfolding of the self and the world. What follows is two research projects that offer some exemplary evidence.

\section{Evidence exemplar 1: reading mathartwork diffractively}

What follows is a diffractive analysis of a 'mathartwork' created by a young South African man to highlight the difference that disciplinary matter, materiality and mattering ${ }^{2}$ makes for research, teaching and learning (Burnard, Sinha, Steyn et al., 2020). We employ the example to emphasise the significant contribution that can be made to transdisciplinary creativity and diffractive analysis that leads to posthumanist theorisations (Fig. 1).

This young man (Fig. 1) seems to offer a self-portrait as a way of being and becoming in the math-art space. In Jubalani's image, maths is inscribed on his body, divided by shadings, axes and ruler markings. Maths is embodied, here; maths is performed. His math-art "work" is abundantly metaphoric in its demarcations of black and white sides of the body, a peeping eye, and the mathematical symbols wrapping, tying down his arm, framing him with the grid and flying off in the background. We see maths in an affective space. In keeping our rhizomatic and diffractive lens alive, we asked what else is going on? Why did Jubalani choose to draw himself? How is a self-portrait, an indication of a life lived, related to mathematical knowings? His image seems to be screaming.There is a great deal of detail concerning the body and its regulation. The bi-tonal hands, and marked distinctions between the shadings of the left and right side shed light on the relational nature of thinking with and through 'mathness' and 'artness' in the world. Jubalani communicates stress; his discomfort with maths is tangible. Is Jubalani envisaging what might be possible and hoping to bring about a change in himself as he becomes aware of how the mathematics and art 'work', connect, overlap and change, creating a math-art interference; what we call 'learning'?

\footnotetext{
$\overline{2}$ The distinctions between matter, materiality and mattering are significant to building a rhizomatic inquiry and analysing data diffractively. Foregrounded by Barad, here matter refers to disciplinary theories, concepts or curricula, while materiality relates to the materials, apparatus or symbols that facilitate an activity or disciplinary process. Mattering, on the other hand, relates to what matter means, what it means to matter or what comes to matter and what does not. Barad (2007) defines it as the "entanglement of matters of being, knowing, and doing, of ontology, epistemology, and ethics, of fact and value, so tangible, so poignant" (p. 3)
} 


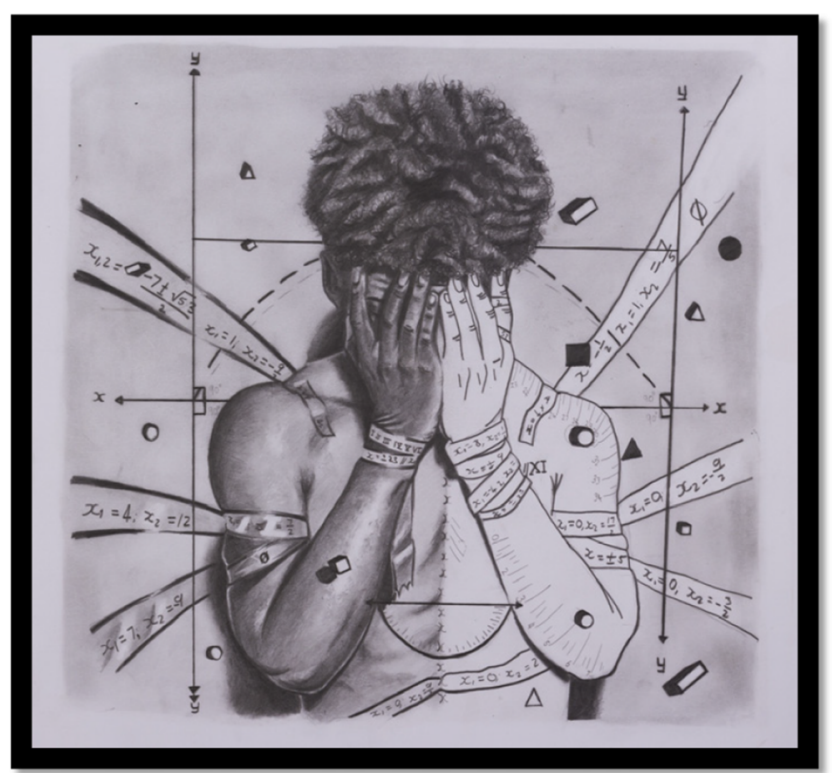

Fig. 1 Stressed Vitruvian man, mathartwork and artist statement by Jubalani

We are invited into a complex world of Jubalani's math-art entanglement as mathematician and artist. How is art offering a power-relegating intra-action between mathematics and the arts in the learning experience of STEAM? How do arts empower students' affective and creative capacities whilst simultaneously improving and fostering understanding of the complexities of the differing matter, materiality and mattering that different disciplines bring with them?

The critical issues here are that there are no inherent and clear borders between matter and discourse, being and knowing, and being and doing. This makes knowing of mathematics and art just as much a matter of the body and the material, as it is a matter of the mind and the intellectual, all of which cannot be separated. Barad (2007) states that the point is not that knowing has material consequences, but "practices of knowing are specific material engagements that participate in (re)configuring the world" (p. 91).

\section{Evidence exemplar 2: reading STEAM gardens diffractively}

How does deterritorialisation work in schools? How does it operate? And most importantly, how is it experienced by children? Formal schooling often sits in stark contrast with the realities of children's lives, or at least those who do not fit the middle-class standard of education, which promotes the cerebral over the practical. Another important question is whether school curricula with their emphasis on literacy and numeracy are fit to deal with widening social inequities and mounting environmental crises. Following the quest initiated by Perry (2020), how can we find ways to incorporate a much broader understanding of the relational human experience, starting from the school grounds?

Researcher's statement: This is a picture (Fig. 2) taken at the start of a pilot project involving children growing food in school gardens in an area of social and economic deprivation. As one of the field researchers, I took the picture of the school grounds at the start of the project. The familiarity of the appearance of this school hardly generates any questions, beyond the fact that the grounds host special equipment for 'exercising' the children's bodies along the designated 'tracks' of the wooden bars and stumps.

Ivinson and Renold (2013) remind us of the supremacy and power of the brain over the body in formal schooling. Children's bodies are somehow 'forgotten' when habituated to sit in enclosed spaces for long hours; then bodies are being 'exercised' to follow fitness guidelines, or left to adapt to the local gendered patterns. The passivity of the body goes hand in hand with the negation of its multiplicity and diversity; and its ability to draw cultural and affective connections with the world. In the project we refer to here (Gray, Colucci-Gray et al. 2019), children were invited to take a central role in redesigning their school grounds into growing spaces. Children were encouraged to imagine what the garden space might look like; what produce might be grown and where; and what amount of resources (soil, water, light) might be needed.

Researcher's statement: This picture (Fig. 3) was taken during a visit to the school seven months later. There

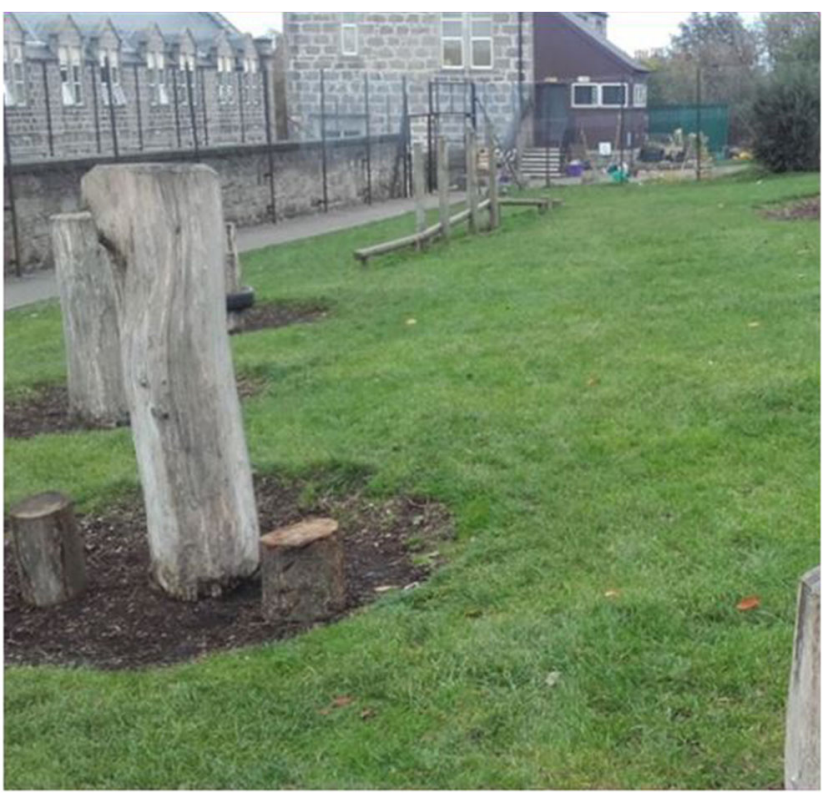

Fig. 2 School grounds, city of Aberdeen, Scotland (October 2018; permission was granted by the School for the use of pictures for research and publication purposes beyond the life of the project) 


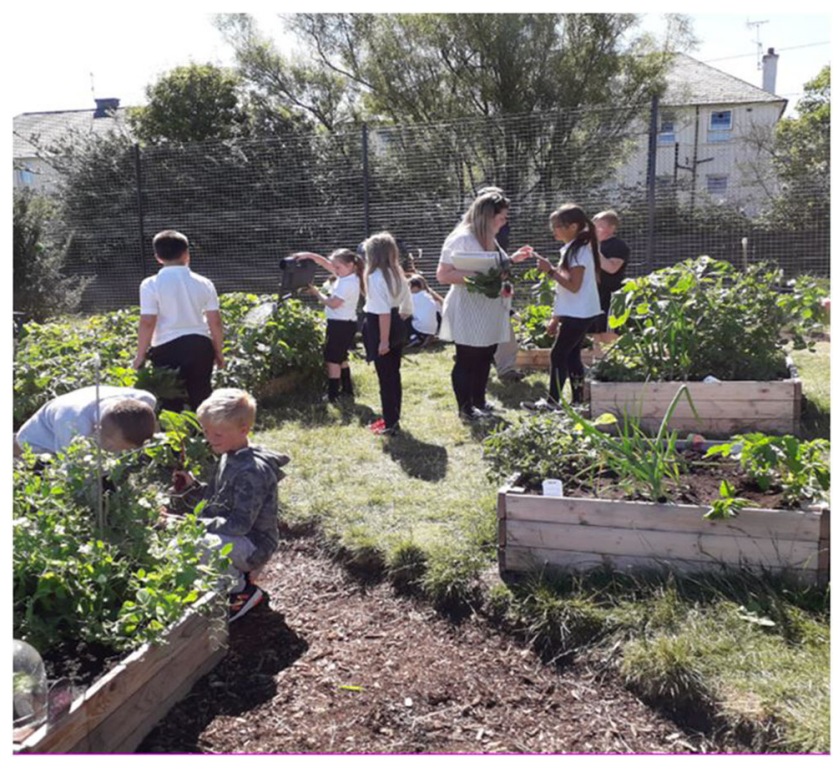

Fig. 3 Children working in the garden (May 2019; permission was granted by the School for the use of pictures for research and publication purposes beyond the life of the project)

was a noticeable change; the exercise equipment had not been dismissed; but the trajectories children could take in the garden had diversified: "with a garden, there are many more possibilities", said one of the boys to me, while showing me around.

In this project, children explored what might be possible in the constrained space of their schoolground; and also considered how to tackle the politics of the space. Different modes of thinking were engaged in an effort to identify the "real, perhaps underlying and hidden, problem to solve, rather than the one that was visible and obvious at the start" (Culen and Gasparini 2019, p. 94). If the original problem here was to produce more food, the underlying problem was largely to justify this as an activity of value for both the children and the teachers. ${ }^{3}$ The children experienced a plurality of connections with a multiplicity of worlds. They attended to the world of the lettuce which died from lack of water, physically feeling the changes in its formerly plump leaves; and the world of the potato, whose long stem is so fragile to handle that "you need to water it gently, from the top or it will snap ... and the plant will die" (girl, aged 11). In 'paying attention' to the processes taking place in the garden, ethics is entangled with aesthetic relationality (Colucci-Gray 2020), whereby the survival of the plants 'matters' and so do the children, in a reciprocal dance of material entanglements, in which one becomes through and by means of the other, diffractively (Barad 2007). As eloquently described by Ivinson (2020), "the need to know

\footnotetext{
$\overline{3}$ The STEAM garden project was implemented by a team of primary teachers and researchers; the teachers had different 'specialisms' in the school (science, drama; languages), while the researchers are former biology teachers.
}

comes from the milieu in which [children] are living" (p. 24). Yet we argue that such a milieu is not only given, but it can be 'brought into being' at school. This is the essence of a STEAM garden: a place where the emphasis shifts from powerful to living knowledge.

\section{Part 3: the call: why posthumanist transdisciplinary pedagogies matter}

What is the thinking and practice being advanced by these kinds of deterritorialising practices and how might this way of working deterritorialise subject learning systems? How can a multiplicity of creativities generate change, and push the boundaries of human-centred thinking towards new territories of transdisciplinary combining and/or pairing of subject disciplines?

We propose new transdisciplinary ways of entangling subject disciplines not simply as acquisition of knowledges and skills, but as important activities with the potential to make a real impact on one's life and one's community. The environmental crisis has exposed the materiality nonhuman life as central, both as vulnerable but also as a productive and vital force (Braidotti 2019; Barad 2007). The aim for education is thus to affirm more strongly the role of subjectivity in learning not restricted to bound individuals or subject silos, but is rather a co-operative trans-species effort "that takes place transversally, in-between nature/ technology; male/female; black/ white; local/global; present/past - in assemblages that flow across and displace the binaries" (Braidotti 2019, p, 33).

Here we argue for much greater understanding of the logics of knowing differently in the arts and sciences, and the diverse and multiple creativities they shape and cultivate in practice. Importantly, we seek to inquire into not only how arts and sciences purposefully connect, but how they stimulate different forms of logics, rationality and affect; how they become part of an inquiry that is embedded within the posthumanist times and the new normal of a COVID-19 world.

Central to this endeavour is to develop ways in which areas of the curriculum may integrate/configure differently.

The integration of scientific and artistic perspectives brings forth analytical thinking and empathetic thinking, offering a range of different modalities for 'dwelling' with objects of attention, of thinking and being in the world. A posthumanist STEAM pedagogy is thus one which offers the unique opportunity for children to develop an understanding of the world that values their affective subjectivities while at the same time enables their relational capabilities to be with and think with other living things, within a shared learning ecology. 
For teachers, letting arts and science teach together might involve a set of negotiated co-authorings with a community of transdisciplinary teachers and learners. The learning 'ecologies' will produce tacit understandings, inferred practices and theoretical assumptions which can be made explicit as new forms of knowledge that generate and diffract into new transdisciplinary practices and processes. Letting arts and science teach together will open up ways of making that require makers to work with and to shape a new reality. Letting arts and science teach together has the potential to cultivate different capacities, which has broader implications for society, politics, the economy and the environment. Letting arts and science teach together offers up a potent practice for integrating knowledge, skills and insights from different domains, and defying established templates.

\section{References}

Barad, K. (2007). Meeting the universe halfway: Quantum physical and the entanglements of matter and meaning. Durham: Duke University Press.

Barad, K. (2014). Diffracting diffraction: Cutting together-apart. Parallax, 20(3), 168-187.

Braidotti, R. (2019). A theoretical framework for the critical posthumanities. Theory, Culture \& Society, 36(6), 31-61.

Burnard, P. and Colucci-Gray, L. (2020). Why science and art creativities matter: STEAM (re-)configurings for future-making education. (critical issues in education). Brill.

Burnard, P., Sinha, P., Steyn, C., Fenyvesi, K, Brownell, C., Werner, O. and Lavicza, Z. (2020). Reconfiguring STEAM through material enactments of mathematics and arts: A diffractive reading of young people's intradisciplinary math-artworks. In Burnard, P. and Colucci-Gray, L. (Eds). Why science and Art Creativities Matter: STEAM (re-)Configurings for future-making education. (Critical issues in education), pp. 171-200. The Netherlands: Brill-I-Sense Publishers.

Colucci-Gray, L. (2020). Developing an ecological view through STEAM pedagogies in Science education. In L. Colucci-Gray, \& P. Burnard (Eds.), Why Science and Art Creativities Matter: (ReConfiguring STEAM for Future-making Education (Vol. 18). (Critical issues in the future of learning and teaching). The Netherlands: Brill-I-sense publishers.
Colucci-Gray, L., Perazzone, A., Dodman, M., \& Camino, E. (2013). Science education for sustainability, epistemological reflections and educational practices: From natural sciences to trans-disciplinarity. Cultural Studies of Science Education, 8(1), 127-183.

Culen, A. L., \& Gasparini, A. (2019). STEAM education: Why learn design thinking? In Z. (Ed.), Promoting language and STEAM as human rights in education science, technology, engineering, arts and mathematics (pp. 91-108). Berkeley: Springer.

Deleuze, G., \& Guattari, E. (1987). A thousand plateaus: Capitalism and schizophrenia (B. Massumi, Trans. Minneapolis: University of Minnesota Press.

Fox, N. J., \& Alldred, P. (2013). The sexuality-assemblage: Desire, affect, anti-humanism. The Sociological Review, 61(4), 769-789.

Funtowicz, S., \& Ravetz, J. R. (1994). Uncertainty, complexity and postnormal science. Environmental Toxicology and Chemistry, 13(12), 1881-1885.

Gray, D., Colucci-Gray, L., Donald, R., Kiriacou, A., \& Wodah, D. (2019). From oil to soil. Learning for sustainability and transitions within the school garden: A project of cultural and social re-learning. Scottish Educational Review, 51(1), 57-70.

Ivinson, G. (2020). The power of living knowledge: Re-imagining horizontal knowledge. Asia-Pacific Journal of Teacher Education, 48(1), 15-29. https://doi.org/10.1080/1359866X.2019.1696453.

Ivinson, G., \& Renold, E. (2013). Subjectivity, affect and place: Thinking with Deleuze and Guattari's body without organs to explore a young teen girl's becomings in a post-industrial locale. Subjectivity, 6(4), 369-390.

MacDonald, A., Wise, K., Riggall, J., \& Brown, N. (2019). Converging discipline perspectives to inform the design and delivery of STEAM teacher professional learning. Australian Art Education, 40(1), 6788.

Perry, M. (2020). Pluriversal literacies: Affect and relationality in vulnerable times. Reading Research Quarterly. Advance online publication. https://doi.org/10.1002/rrq.312.

Petrie, H. G. (1992). Interdisciplinary education: Are we faced with insurmountable opportunities? Review of Research in Education, 18, 299-333.

Russell, A. W., Wickson, F., \& Carew, A. (2008). Transdisciplinarity: Context, contradictions and capacity. Science Direct Futures, 40, $460-472$.

Smith, S., \& Henriksen, D. (2016). Fail again, fail better: Embracing failure as a paradigm for creative learning in the arts. Art Education, 69(2), 6-11.

Publisher's note Springer Nature remains neutral with regard to jurisdictional claims in published maps and institutional affiliations. 